IZA DP No. 3997

\title{
Latina Entrepreneurship
}

\author{
Magnus Lofstrom
}

Timothy Bates

February 2009 


\title{
Latina Entrepreneurship
}

\author{
Magnus Lofstrom \\ Public Policy Institute of California \\ and IZA \\ Timothy Bates \\ Wayne State University

\section{Discussion Paper No. 3997 \\ February 2009} \\ IZA
P.O. Box 7240
53072 Bonn
Germany \\ Phone: +49-228-3894-0 \\ Fax: +49-228-3894-180 \\ E-mail: iza@iza.org
}

\begin{abstract}
Any opinions expressed here are those of the author(s) and not those of IZA. Research published in this series may include views on policy, but the institute itself takes no institutional policy positions.

The Institute for the Study of Labor (IZA) in Bonn is a local and virtual international research center and a place of communication between science, politics and business. IZA is an independent nonprofit organization supported by Deutsche Post Foundation. The center is associated with the University of Bonn and offers a stimulating research environment through its international network, workshops and conferences, data service, project support, research visits and doctoral program. IZA engages in (i) original and internationally competitive research in all fields of labor economics, (ii) development of policy concepts, and (iii) dissemination of research results and concepts to the interested public.
\end{abstract}

IZA Discussion Papers often represent preliminary work and are circulated to encourage discussion. Citation of such a paper should account for its provisional character. A revised version may be available directly from the author. 
IZA Discussion Paper No. 3997

February 2009

\section{ABSTRACT}

\section{Latina Entrepreneurship*}

We utilize individual panel data from the 1996 and 2001 Survey of Income and Program Participation (SIPP) to analyze the relative success of self-employed female Hispanics. To allow for a meaningful comparison of earnings between self-employed and wage/salary employed women, we generate different earnings measures addressing the role of business equity. We compare earnings of Hispanic female entrepreneurs to both Latina wage/salary workers and to self-employed female non-Hispanic whites. Latina entrepreneurs are observed to have lower mean earnings than both white female entrepreneurs and Latina employees. However, our findings indicate that Latina entrepreneurs often do well, once differences in mean observable characteristics, such as education, are taken into account. Self-employed Latinas are estimated to earn more than observationally similar nonminority white female entrepreneurs and slightly less than observationally similar Latinas in wage/salary work.

JEL Classification: J15, J16, J31, L26

Keywords: $\quad$ self-employment, entrepreneurship, female, minority, Hispanic, Latina

Corresponding author:

Magnus Lofstrom

Public Policy Institute of California

500 Washington Street

Suite 600

San Francisco, CA 94111

USA

E-mail: lofstrom@ppic.org

\footnotetext{
* We thank Rob Fairlie, William Jackson and participants at the 2008 Research Conference on Entrepreneurship Among Minorities and Women, University of North Carolina, Chapel Hill for helpful comments.
} 


\section{Introduction}

The limited labor market success among the largest and fastest growing minority group in the U.S. - Hispanics - is of concern to many, including policy makers. Clearly, identifying policy tools capable of improving labor market outcomes is important. In this paper, we address the question of whether self-employment should be considered as such a policy tool, specifically to broaden the labor market alternatives of Latinas. However, before policies designed to assist Latinas contemplating entry into self-employment are implemented, we need to explore evidence of the degree of success realized by those choosing self-employment -- what kinds of earnings expectations are realistic? For targeting purposes, it is also important to identify factors associated with earnings success, or possibly, lack-thereof, among present and potential Latina entrepreneurs.

We are struck by the lack of baseline information describing Hispanic-Americans who own small businesses and, or pursue self-employment as a primary labor-force activity. While an occasional paper has discussed Latino entrepreneurship generally, we are aware of only one other study (Fairlie and Woodruff, 2007) that analyzes entrepreneurship among Latinas. Beyond merely describing traits and performance of Latina entrepreneurs and the firms they own, we seek to compare entrepreneurship as an option to working as an employee. Do Latinas earn more, on average, as entrepreneurs or employees? Controlling for human capital, financial capital, and demographic traits, is entrepreneurship a pragmatic choice in the sense of generating earnings that are at least comparable to those available to similar persons choosing to work as employees? Do mean statistics on self-employment earnings mask greater variance of returns to 
entrepreneurs as opposed to employees? Relative to nonminority female entrepreneurs, how do the self-employment earnings of Latinas compare?

Self-employment among women (as opposed to men) differs in several broad respects, including patterns of industry concentration and the incidence of part-time pursuit of self employment. We have chosen to restrict our analysis to Hispanic and nonminority women who have exhibited serious labor-force attachment: self-employed persons specifically are defined as "self employed" only in cases where their average hours per week devoted to entrepreneurship exceeds $25 .{ }^{1}$ Thus, we are ignoring women working less than 25 hours weekly in their small business/self employment activities.

Our data indicate that self-employed Latinas are on average a relatively disadvantaged group from the perspective of socioeconomic status, including educational attainment. However, our overall findings positively portray the entrepreneurship option among Latinas. Generally strong earnings, which include returns to owner investments of financial capital in their small businesses, measure up well, relative to employee earnings. A major component of “earnings” identified by our analysis consists of returns to financial capital investments owners have made in their firms. Entrepreneurial earnings, however, exhibit high variability; extreme values, in particular, typify the tails of the distribution - earnings performance of the top tenth and the bottom tenth of the self-employed are examined to illustrate this pattern.

Relative to nonminority women, finally, we find that the "Latina" trait, other factors constant, is associated with higher self-employment earnings. In the context of linear regression analysis, otherwise identical individuals -- regarding human capital,

\footnotetext{
${ }^{1}$ Similarly, in our analysis we restrict female employees to those who report typically working at least 25 hours per week.
} 
financial capital, and other traits -- who differ only in terms of the ethnic characteristic, are different in that Hispanic women entrepreneurs generate higher earnings than nonminority women. This fact bolsters our conclusion that entrepreneurship among Latinas is broadly successful in the sense of generating attractive monetary returns to those pursuing their small-business/self-employment activities 25 or more hours per week.

Viewed from the perspective of choice - self-employment or wage/salary work we find that Latina entrepreneurs earn slightly less than their observationally identical wage/salary counterpart. Our results also indicate that self-employed Latinas would typically receive higher annual earnings had they chosen wage/salary work. ${ }^{2}$ These results suggest that Latina entrepreneurs opt for self-employment, to some extent, for non-pecuniary reasons.

\section{Data}

Our data are derived from the 1996 and 2001 panels of the Survey of Income and Program Participation (SIPP) and cover the four year period from 1996 to 1999 and the three year period from 2001 to 2003. The 1996 and 2001 SIPP surveys are rotating panels made up of 12 and 9 waves of data respectively for the 1996 and 2001 panels. The surveys (waves) were conducted every four months, tracking the same individuals/households, for approximately 37,000 U.S. households in each panel.

Both the 1996 and 2001 panels over-sampled low-income households and hence sampling weights are used throughout our analysis, making the data nationally

\footnotetext{
${ }^{2}$ The choice of self-employment or wage/salary work is not modeled in our analysis below. Hence, the estimated hypothetical earnings of Latina entrepreneurs in wage/salary work may not be a true reflection of Latinas' counterfactual earnings in employment.
} 
representative. As with previous SIPP panels, each wave contains both core questions, common to each wave, and topical questions that are not updated in each wave. In addition to the core variables, we use information from two topical modules: immigration (which includes information on country of origin as well as year of arrival) and assets and liabilities (containing wealth, asset and business equity data, collected each year in waves 3, 6, 9 and 12).

\section{Profile of Nonminority and Hispanic Women Active in the Labor Market}

Our sample is restricted to Hispanic and non-Hispanic white females between the ages of 20 and 64 who reported working either in wage/salary work or in their own business at least 25 hours in a typical week. The restrictions yielded a sample of 29,218 females (2,285 in self-employment and 26,933 in wage/salary work). Sample statistics, by ethnicity, are shown in Table 1.

\section{Table 1 here}

Self-employed business owners irrespective of race and ethnicity tend to be relatively well educated in comparison to other labor market participants, and their average household net worth amounts tower above those typifying non-business owners (Bates, 1997). Because the adult female Hispanics and white non-Hispanics compared in table 1 differ hugely in terms of educational attainment and mean net worth amounts, the latter predictably are much more likely than the former to be self employed. NonHispanic white women are over twice as likely to be college graduates (Table 1) while Hispanic women are six times more likely than their nonminority counterparts to lack a high school diploma. Possessing over twice the household net worth of Hispanic women, 
on average, nonminority white women are much more likely to possess the human-capital and financial-capital characteristics most often associated with small business ownership. In fact, 5.7 percent of the Hispanic women under consideration are self employed, as opposed to 7.8 percent of the non-Hispanic white women (Table 1).

Being a more highly educated, high net worth subgroup, relative to Hispanic women, white women predictably report higher overall average annual earnings $(\$ 28,568$ vs. $\$ 21,117)$ than their Hispanic counterparts. Among the latter subgroup, 44 percent are immigrants, as opposed to 3 percent of white women (Table 1). Nonminority women, finally, are slightly older and more likely to be married, in comparison to the Hispanic women described in Table 1.

\section{Measures of Success - Earnings Variables Defined}

Our objective is to assess the relative success of female Hispanic entrepreneurs compared to female Hispanic wage/salary workers and to non-Hispanic white female entrepreneurs. The measures of success used in this paper are based on annual earnings because these outcome measures closely reflect the overall economic well being of individuals.

An important issue to consider when comparing earnings between the selfemployed and wage/salary workers is the fact that self-employment earnings do not only represent returns to human capital but also returns to financial capital invested in the business. That is, reported self-employment earnings partially reflect a return to owner investments made in the business while wage/salary earnings do not. We therefore generate two earnings measures: The first simply adds to annual earnings annual asset 
income received from financial capital, i.e. stocks, bonds, real estate and other investments, which is observed for both the self-employed and wage/salary workers. Total annual earnings and capital income are hence an income measure that includes returns to physical and financial capital for self-employed individuals as well as workers in wage/salary employment.

A second (alternative) approach entails subtracting a portion of the earnings of the self-employed, which roughly represents owner returns to investments of resources cash, inventory, equipment, and the like, net of debt -- in their small businesses. Hence, we utilize the reported dollar amount of business equity information available in SIPP and subtract from annual earnings an amount equal to 10 percent of this business equity, representing a return to a rather risky, illiquid investment. Use of the 10 percent figure is a reflection of the opportunity cost of capital. By assumption, alternative investments into which this business equity dollar amount could be deployed would be expected to earn a ten percent rate of return. By way of example, an owner reporting a $\$ 50,000$ business equity amount, along with annual net profits of $\$ 40,000$, would be assumed to have earned $\$ 5,000$ as a return on her business equity investment. The balance - profits of $\$ 35,000$ - is attributed to the owner’s returns for time spent working in her small business. We refer to this measure as "business equity-adjusted" earnings, which we interpret as an income measure that reflects only returns to human capital for both employed workers and the self-employed.

By definition, the above earnings measures do not reflect the total returns to selfemployment, which may also include changes in the value of the business (which may be either positive or negative) that the entrepreneur generated over the year. Our last 
earnings measure adds the annual change in business equity (the increase or decrease in the net value of the small business) to the business equity-adjusted earnings measure and is referred to as business equity-adjusted earnings, including annual changes in business equity. Clearly, the latter adjustment to annual earnings applies only to business owners; since this measure includes year-over-year changes in business equity, it requires that the individual was observed to be self-employed in consecutive years, i.e. at least one year. Hence, the sample size utilizing the measure taking into account annual changes in business equity is smaller $(1,279$ entrepreneurs, compared to the full sample of 2,288 self-employed women).

\section{Traits of the Self Employed and Wage and Salary Workers}

A comparison between Hispanic and white entrepreneurs shows that Hispanic women have substantially lower schooling levels (close to 1/3 are high school dropouts), are far more likely to be immigrants, work slightly fewer hours per week, have on average owned theirs businesses two years less, and, finally, possess on average significantly less household net worth than nonminority white women (Table 2). All earnings measures indicate lower earnings among the self-employed female Hispanics. Total annual earnings, for example, average \$26,908 for self-employed non-Hispanic women, well above the corresponding figure of \$20,853 describing Hispanic women.

\section{Table 2 here}

Self-employed Latinas have lower schooling levels, have greater potential labor market experience (due to both age and less schooling) and work more hours per week, 
compared to their wage/salary counterparts. Also, mean household net worth is greater among Latina entrepreneurs. Furthermore, 61 percent of Latina entrepreneurs are immigrants while "only" 43 percent of employees are foreign born. Finally, the table also shows that self-employed female Hispanics have lower mean earnings, by all earnings measures, than Latinas in wage/salary employment. Table two's summary statistics therefore suggest that Hispanic women who own and operate their own firms lag behind key comparison groups - Latina wage and salary workers as well as the non-Hispanic self-employed women - in terms of their average earnings. In the case of Latina wage and salary workers versus the self-employed, the earnings differential (measured by total annual earnings) is slight - mean earnings are $\$ 21,133$ for employees versus $\$ 20,853$ for the owners of small businesses.

It is noteworthy that self-employed Latinas as a group exhibit lower levels of educational attainment than Latina wage and salary workers: 15 percent of the latter, for example, are college graduates, versus 13 percent of the former. Wage workers, furthermore, are much more likely to have attended college but not graduated: 31 percent were in this education category versus only 22 percent of the Latina business owners. Finally, 32 percent of the Latina self employed had not graduated from high school, as opposed to 25 percent of the Latina wage workers. The non-Hispanic women, whether self employed or wage workers, rarely lacked high school degrees and exhibited similar levels of educational attainment overall (Table 2). Earnings comparisons therefore necessitate econometric controls for such key traits as levels of educational attainment, and this exercise is conducted in upcoming sections of our analysis. 
Another key aspect delineating the wage workers for the self employed is the substantial variance in earnings typifying the latter group. Table 3 explores this aspect of earnings by reporting median earnings as well as earnings reported by the top and bottom deciles and quartiles of wage workers and the self employed. Predictably, the top decile of self employed earners, whether Latina or nonminority, reports higher total annual earnings than wage workers and the bottom decile reports lower earnings. When equityadjusted earnings are considered, particularly when changes in business equity is included in earnings, the top deciles of the self employed report much higher earnings than wage workers -- $\$ 52,805$ versus $\$ 40,685$ in the case of Latinas and $\$ 115,648$ versus $\$ 53,340$ among white women. Self-employed female Hispanics in the bottom quartile of the total annual earnings distribution exhibit the opposite pattern: they do significantly worse than employed Hispanics in the bottom quartile. This earnings variance pattern is broadly consistent across the different earnings measures (Table 3).

\section{Table 3 here}

\section{Analysis of Earnings Differentials}

Tables 2 and 3 reveal that Latina entrepreneurs earn significantly less than female white entrepreneurs. These tables also show that self-employed Latinas have on average lower earnings than their wage/salary counterpart. In this section we analyze determinants of these gaps, starting with the white-Latina self-employment earnings gap.

Compared to self-employed white females, one factor in particular is likely to contribute to the lower earnings among Latina entrepreneurs - the lower levels of educational attainment of Latinas (Table 2). We generated average annual earnings by 
educational attainment for the two ethnic groups, shown in Table 4. Quite strikingly, the table shows that self-employed Latinas do very well compared to white female business owners of similar schooling levels. Relatively educated Latinas in particular fare well in a comparison with their self-employed white female counterparts. For self-employed women with less than a college degree, the differences are overall quite small and the table convincingly shows that education is a key factor in explaining differences in earnings between the two groups.

\section{Table 4 here}

The observed differences in earnings across groups may also, at least partially, be due to differences in other observable productivity related characteristics, as discussed above. To assess the role of these specific observables on earnings, and differences, we estimate linear regression models. The estimated coefficients are then used to decompose observed differentials along the lines of a Blinder-Oaxaca decomposition.

The portrait of small businesses earning high profits is one of highly educated owners working full-time in their firms (Bates,1997). The older, more established firms, furthermore, tend to generate higher returns than the newcomers. Note that dollar measures of self-employment/small business returns have an inherent randomness rooted in reality of widely ranging accounting conventions regarding inventory valuation, depreciation methods, and the like. Such randomness complicates the task of establishing statistically significant relationships between dependent variable measures of firm returns and the various independent variables. We find nonetheless that our decomposition of earnings differences characterizing the Latina and non-Hispanic women entrepreneurs is 
quite consistent with our expectations of substantial owner human-capital differentials generating large earnings differentials.

Table 5’s income measures indicate that higher self-employment earnings (unadjusted for business equity) typify the better educated group of the self employed, non-Hispanic women, who averaged $\$ 23,316$, as opposed to $\$ 18,697$ for Latina entrepreneurs. A linear Blinder-Oaxaca decomposition (Table 5) reveals that this entire $\$ 4,619$ earnings differential $(\$ 23,316-\$ 18,697=\$ 4,619)$ is explained by differences in endowments. The OLS regression analyses of self-employment earnings upon which this analysis is based are shown in appendix Table A1.

\section{Table 5 here}

Table 5 further shows the results of the Blinder-Oaxaca decomposition using different measures of self-employment earnings that adjust first, for the opportunity cost of business equity and second, for the change in business equity over the observed life of the small firm. The results quite clearly, and consistently across earnings measures, show that three key factors largely explain the lower self-employment earnings of Hispanic women.

First, lower educational attainment alone explains more than 100 percent of the observed gap in the mean self-employment earnings of nonminority women and Latinas. This is not surprising given the descriptive statistics shown in Table 4. Among equally educated women, Table 5's decomposition of earnings differentials indicates that Latinas have higher expected self-employment earnings than whites; this is true irrespective of the earnings measure under consideration. Second, immigrants tend to earn lower selfemployment returns than persons born in the U.S., other things being equal (see our OLS 
regressions explaining self-employment earnings: Table A1). The substantially greater proportion of immigrants among Hispanics thus contributes considerably to the gaps in self-employment earnings (Table 5). A word of caution is warranted here since the immigrant and years since migration effects are not very precisely estimated, and some of these estimates are not statistically significant in certain models. Nonetheless, the results do suggest that nativity is one of the contributing factors to the lower earnings of Latina entrepreneurs.

Finally, fewer years owning the business translates into lower self-employment earnings, other factors constant, and Latina-owned businesses are younger, on average, than those owned by nonminority women. Findings of Table 5's self-employmentearnings decomposition suggest that if female Hispanic entrepreneurs were observationally identical to female white entrepreneurs, they would earn, depending on the earnings measure used, between 27 to 44 percent more than white entrepreneurs. It is worthwhile to explore explanations for the finding that observationally similar Latinas are predicted to outperform white female entrepreneurs. First, we looked at whether the geographic distribution is a partial factor, That is, Latinas are more likely to live in some states with high average earnings, such as California. However, the overall decomposition analysis does not change appreciably when state controls are included in the estimated earnings regressions models (results not shown but available upon request). Including state controls, however, did have an impact on the immigration estimates and the role of nativity in explaining the earnings gap. These estimates are now more imprecise and indicate a smaller contribution to the gap from immigration, further 
cautioning us from drawing strong conclusions regarding the role of immigration as an explanation for the lower unadjusted Latina self-employment earnings.

Other possible explanations for the predicted higher Latina earnings include stronger positive selection into self-employment among Latinas than whites. It is also possible that our covariate estimates do not represent their true effect on earnings due to the presence of unobserved individual heterogeneity, which presumably is correlated with some of our covariates and currently captured by the error term, yielding biased estimates. All of these explanations may indeed be relevant factors. However, it is also worthwhile pointing out that the key finding from this exercise is the role of education in explaining most, if not all, of the white-Latina earnings gap. The simple comparison of mean earnings by educational attainment, Table 5, strongly indicated this with far fewer assumptions necessary to make than the ones made in the standard linear regression framework.

\section{Earnings Differentials - Self-Employed and Wage/Salary Latinas}

Our final objective is to assess how well self-employed Latinas do in the labor market, compared to their wage/salary counterparts. Table 6 summarizes Latina mean total annual earnings differentials, using three income measures - 1) unadjusted total annual earnings, 2) business-equity-adjusted annual earnings, and 3) annual earnings, including capital income, adjusted for business equity amount and change in business equity. Using the unadjusted total earnings measure, we observe a small difference across sectors - employed Latinas averaged $\$ 21,133$ in annual earnings, as opposed to $\$ 20,853$ for Latina entrepreneurs (column 1). 
As expected, a greater difference emerges when returns to business equity are subtracted from total annual earnings. Our adjustment assumes a 10 percent opportunity cost of capital. Self-employed Latinas' average equity- adjusted earnings are now $\$ 16,547$, representing slightly more than 78 percent of the average earnings amongst wage/salary Latinas column 2). The applicable gap, of course, narrows if we assume that the opportunity cost of capital is less than 10 percent.

Our last measure, which adds reported capital income for both wage/salary workers and the self-employed, indicate an annual earnings gap of $\$ 3,435$, implying that Latina entrepreneurs receive approximately 84 percent of the average earnings of their salaried counterparts (column 3). Although the observed mean earnings differences are sensitive to the earnings measure used, Table 6 shows that Latinas in self-employment report lower earnings than wage/salary Latinas across all three measures. ${ }^{3}$

The lower earnings of Latina entrepreneurs may be due to observable factors -particularly their relatively lower schooling attainment levels and greater share of immigrants, (see Table 2). To assess the role of observable characteristics in explaining the earnings gaps typifying Latina wage/salary workers versus entrepreneurs, we employ two hypothetical earnings scenarios. First, we predict the earnings of self-employed Latinas under the assumption that they possess the characteristics/endowments of wage/salary Latinas. Secondly, we predict total earnings of Latina entrepreneurs had they chosen to work in the wage/salary sectors (Table 6).

Column (1) of Table 6 indicates that the small gap in total annual earnings is entirely explained by differences in endowments and that self-employed Latinas would

\footnotetext{
${ }^{3}$ Note that, unlike in our ethnic self-employment earnings gap analysis, the earnings measures utilized here are based on total annual earnings which include reported earnings from, if relevant, both self-employment and wage/salary work.
} 
do quite well had they chosen wage/salary work. In fact, they are predicted to have slightly higher mean earnings in wage/salary employment than the Latinas who were observed employed in wage/salary work.

Turning to our business-equity-adjusted earnings measure, column (2), we see that Latina entrepreneurs earn $\$ 4,586$ less than their wage/salary counterparts. Controlling for differences in observable characteristics, the gap using this measure shrinks to $\$ 2,828$, implying that about $\$ 1,758$, or 38 percent, of the $\$ 4,586$ gap is due to differences in observable characteristics.

Our final earnings measure (column 3) is business-equity adjusted to reflect the opportunity cost of capital the owner has invested into the firm and includes capital income and changes in business equity. Controlling for observable traits we find that the earnings gap of $\$ 3,434$ actually increases to $\$ 6,778$. This peculiar result appears to be related to the change in the sample occurring when change in business equity is factored into the analysis of earnings differentials. The sample size of self-employed Latinas falls in this situation because business-equity information for multiple points in time is not available for many of the underlying small businesses. Furthermore, this sub-sample is not a random sample of Latina entrepreneurs since it is conditioned on staying in business. That is, entrepreneurs who abandoned their business during the year are likely to be less successful than the ones who stay in business. Table A2 reveals that the sample selection effect appears to have a strong impact on the estimates of the returns to labor market experience. A closer look reveals that this combined with the lower years of 
experience amongst wage/salary Latinas entirely explain why the predicted earnings gap increases when we use the characteristics of Latina employees. ${ }^{4}$

In light of the non-random sample selection, and sample-size constraints, we are however inclined to treat these findings as speculative and to emphasize, instead, the column (2) conclusion that Latina entrepreneurs earn, on average, an estimated \$2,828 less than their wage/salary cohorts who possess identical traits - education, immigrant status, hours worked, and the like.

Our results indicate that Latina entrepreneurs would have received higher earnings had they chosen wage/salary employment. This suggests that either Latina entrepreneurs' perceptions of their opportunities in the larger salaried sector are inaccurate and/or that they choose self-employment for non-pecuniary reasons. Support for the latter can be found in Lopez and Trevizo (forthcoming) who find that Mexican immigrant entrepreneurs report greater work autonomy and sense of having control over economic outcomes as reasons for selecting to become self-employed.

\section{Conclusions}

Self-employed Latinas possess fewer characteristics that are associated with higher earnings than nonminority white women entrepreneurs and employed Latinas. We show that the differences in observable characteristics are important in explaining the lower mean annual earnings of Latina business owners. Our results are mostly consistent across earnings measures used to evaluate female Hispanic labor market success.

\footnotetext{
${ }^{4}$ In fact, the results indicate higher earnings for Latina entrepreneurs had they possessed the characteristics of their employed counterparts but holding years of experience at the higher mean Latina entrepreneur level.
} 
On the issue of comparative earnings from self employment, we found that the lower average earnings of Latina entrepreneurs are explained by traits such as educational background, when contrasted to earnings reported by nonminority self-employed women. The striking finding is that Latinas possessing the same levels of traits regarding education, immigrant status, and the like actually earn more than their white-women counterparts pursuing entrepreneurship. By this tangible success measure, we judge the average performance of self-employed Latinas favorably. This is qualified by our findings of extremely skewed self-employment earnings, however measured. At the low end of the self-employment earnings distribution, earnings of the self employed are strikingly low, particularly in comparison to wage/salary comparison groups.

Is self employment a rational choice in light of earnings skewness and the higher earnings of Latinas pursuing wage and salary work? Strictly on earnings grounds, the choice of wage work looks safer and, on average, more rewarding. The self-employment option, we suspect, is attractive for many nonetheless for the reasons emphasized by Lopez and Trevizo (fortcoming) — greater work autonomy and control are sufficiently appealing to counterbalance self-employment's disadvantages. Lastly, it should be pointed out that since our estimates are not obtained based on samples randomly drawn into self-employment and wage/salary work, the "self-employment earnings effect” may not represent a true causal effect of business ownership. Nonetheless, we believe this is a good first step, providing suggestive and important results, to the scant analytical literature on Latina entrepreneurship. 


\section{References}

Bates, Timothy. (1997). Race, Self-Employment, and Upward Mobility. (Baltimore: Johns Hopkins University Press).

Fairlie, Robert W. and Christopher Woodruff. (2007). "Mexican Entrepreneurship”, National Poverty Center Working Paper Series, \#07-34, December 2007.

Fairlie, Robert W. and Christopher Woodruff. (2007). "Mexican Entrepreneurship: A Comparison of Self-Employment in Mexico and the United States" in: G. Borjas (ed.), Mexican Immigration in the United States, NBER-C, pp. 123-158

Hamilton, Barton H. (2000) "Does Entrepreneurship Pay? An Empirical Analysis of the Returns to Self-Employment”, Journal of Political Economy, 2000, vol. 108, no. 3.

Lopez, Mary and Dolores Trevizo (forthcoming) "Mexican Entrepreneurship in Los Angeles: An Analysis of Determinants of Entrepreneurial Success" in Alfonso Morales, David Torres and John Sibley Butler (eds.) American Story: Mexican American Entrepreneurship \& Wealth Creation, Purdue University Press. 
Table 1.

Adult Females Exhibiting Strong labor-Force Attachment: Sample Means by Ethnicity

\begin{tabular}{lcc}
\hline & Hispanic & $\begin{array}{c}\text { White } \\
\text { (Non-Hispanic) }\end{array}$ \\
\hline & & 7.80 \\
Self-Employment Rate & 5.71 & 13.88 \\
Years of Education & 11.85 & 0.04 \\
High School Dropout & 0.25 & 0.30 \\
High School Graduate & 0.30 & 0.35 \\
Some College & 0.30 & 0.32 \\
College Graduate & 0.15 & 40.82 \\
Age & 37.41 & 20.94 \\
Potential Labor Market Experience & 19.56 & 40.12 \\
Hours Work per Week & 38.64 & 0.61 \\
Married & & 0.70 \\
Number of Children & 0.54 & 2.83 \\
Number of Persons in Household & 1.28 & 0.77 \\
Urban Resident & 3.74 & 0.03 \\
Immigrant & 0.91 & 21.96 \\
Years Since Immigration & 0.44 & \\
Total Annual Earnings & 18.25 & $\$ 28,568$ \\
Total Annual Earnings, Business Equity Adjusted & $\$ 20,871$ & $\$ 28,032$ \\
Household Net Worth & & \\
Number of Observations & $\$ 71,393$ & $\$ 153,169$ \\
Number of Individuals & & \\
\hline
\end{tabular}

Source: SIPP 1996 and 2001 panels 
Table 2.

Adult Females Exhibiting Strong Labor-Force Attachment: Sample Means by Sector and Ethnicity

\begin{tabular}{|c|c|c|c|c|}
\hline & \multicolumn{2}{|c|}{ Self-Employed } & \multicolumn{2}{|c|}{ Wage/Salary } \\
\hline & Hispanic & $\begin{array}{c}\text { White } \\
\text { (Non-Hispanic) }\end{array}$ & Hispanic & $\begin{array}{c}\text { White } \\
\text { (Non-Hispanic) }\end{array}$ \\
\hline Years of Education & 11.33 & 13.89 & 11.88 & 13.88 \\
\hline High School Dropout & 0.32 & 0.04 & 0.25 & 0.04 \\
\hline High School Graduate & 0.32 & 0.29 & 0.30 & 0.30 \\
\hline Some College & 0.22 & 0.36 & 0.31 & 0.34 \\
\hline College Graduate & 0.13 & 0.31 & 0.15 & 0.32 \\
\hline Age & 40.21 & 44.44 & 37.23 & 40.51 \\
\hline Potential Labor Market Experience & 22.88 & 24.55 & 19.36 & 20.64 \\
\hline Hours Work per Week & 42.5 & 44.6 & 38.4 & 39.7 \\
\hline Married & 0.66 & 0.73 & 0.53 & 0.60 \\
\hline Number of Children & 1.27 & 0.79 & 1.28 & 0.70 \\
\hline Number of Persons in Household & 3.70 & 2.92 & 3.75 & 2.82 \\
\hline Urban Resident & 0.89 & 0.76 & 0.91 & 0.77 \\
\hline Immigrant & 0.61 & 0.05 & 0.43 & 0.03 \\
\hline Years Since Immigration & 17.9 & 21.7 & 18.3 & 22.0 \\
\hline Total Annual Earnings & $\$ 20,853$ & $\$ 26,908$ & $\$ 21,133$ & $\$ 28,709$ \\
\hline Total annual earnings, business equity adjusted & $\$ 16,547$ & $\$ 20,033$ & $\$ 21,133$ & $\$ 28,709$ \\
\hline Self-Employment Annual Earnings & $\$ 18,697$ & $\$ 23,316$ & $\$ 58$ & $\$ 135$ \\
\hline Wage/Salary Annual Earnings & $\$ 1,241$ & $\$ 2,436$ & $\$ 20,602$ & $\$ 27,839$ \\
\hline Business Equity Adjusted Self-Employment Earnings & $\$ 14,390$ & $\$ 16,441$ & & \\
\hline $\begin{array}{l}\text { Business Equity Adjusted Self-Employment Earnings } \\
\text { with Annual Change in Business Equity }\end{array}$ & $\$ 16,808$ & $\$ 20,001$ & & \\
\hline Household Net Worth & $\$ 128,451$ & $\$ 292,074$ & $\$ 67,939$ & $\$ 141,412$ \\
\hline Business Equity & $\$ 35,833$ & $\$ 55,115$ & & \\
\hline Years in Business & 5.49 & 7.50 & & \\
\hline Job Tenure & & & 5.08 & 7.06 \\
\hline Number of Observations & 460 & 4,962 & 7,667 & 59,124 \\
\hline Number of Individuals & 217 & 2,068 & 3,395 & 23,538 \\
\hline
\end{tabular}

Source: SIPP 1996 and 2001 panels 
Table 3a.

Earnings Measures, Percentiles by Sector, Hispanic Women

\begin{tabular}{|c|c|c|c|c|c|c|}
\hline & \multicolumn{6}{|c|}{ Percentile } \\
\hline & 10 & 25 & Median & Mean & 75 & 90 \\
\hline & \multicolumn{6}{|c|}{ Hispanic } \\
\hline & \multicolumn{6}{|c|}{ Total Annual Earnings } \\
\hline Self-Employed & $\$ 2,800$ & $\$ 6,400$ & $\$ 12,410$ & $\$ 20,853$ & $\$ 20,402$ & $\$ 41,040$ \\
\hline Wage/Salary & $\$ 7,310$ & $\$ 11,340$ & $\$ 17,190$ & $\$ 21,133$ & $\$ 25,876$ & $\$ 39,389$ \\
\hline \multicolumn{7}{|c|}{ Earnings Difference (Self-Employed - Wage/Salary) } \\
\hline Level & $-4,510$ & $-4,940$ & $-4,780$ & -280 & $-5,474$ & 1,651 \\
\hline \multirow[t]{2}{*}{ Percent (of Wage/Salary) } & 38 & 56 & 72 & 99 & 79 & 104 \\
\hline & \multicolumn{6}{|c|}{ Total Annual Earnings, Business Equity Adjusted } \\
\hline Self-Employed & $\$ 0$ & $\$ 4,725$ & $\$ 11,100$ & $\$ 16,547$ & $\$ 18,500$ & $\$ 38,000$ \\
\hline Wage/Salary & $\$ 7,310$ & $\$ 11,340$ & $\$ 17,190$ & $\$ 21,133$ & $\$ 25,876$ & $\$ 39,389$ \\
\hline \multicolumn{7}{|c|}{ Earnings Difference (Self-Employed - Wage/Salary) } \\
\hline Level & $-7,310$ & $-6,615$ & $-6,090$ & $-4,586$ & $-7,376$ & $-1,389$ \\
\hline \multirow[t]{2}{*}{ Percent (of Wage/Salary) } & 0 & 42 & 65 & 78 & 71 & 96 \\
\hline & \multicolumn{6}{|c|}{$\begin{array}{l}\text { Total Annual Earnings (including Capital Income), } \\
\text { Business Equity Adjusted Including Annual Change in Business Equity }\end{array}$} \\
\hline Self-Employed & $\$-13,650$ & $\$ 3,240$ & $\$ 12,075$ & $\$ 18,554$ & $\$ 22,484$ & $\$ 52,805$ \\
\hline Wage/Salary & $\$ 7,880$ & $\$ 11,908$ & $\$ 17,885$ & $\$ 21,988$ & $\$ 26,696$ & $\$ 40,685$ \\
\hline \multicolumn{7}{|c|}{ Earnings Difference (Self-Employed - Wage/Salary) } \\
\hline Level & $-21,530$ & $-8,668$ & $-5,810$ & $-3,435$ & $-4,212$ & 12,120 \\
\hline Percent (of Wage/Salary) & -173 & 27 & 68 & 84 & 84 & 130 \\
\hline
\end{tabular}

Source: SIPP 1996 and 2001 panels 


\section{Table 3b.}

Earnings Measures, Percentiles by Sector, Non-Hispanic White Women

\begin{tabular}{|c|c|c|c|c|c|c|}
\hline & \multicolumn{6}{|c|}{ Percentile } \\
\hline & 10 & 25 & Median & Mean & 75 & 90 \\
\hline & \multicolumn{6}{|c|}{ Non-Hispanic White } \\
\hline & \multicolumn{6}{|c|}{ Total Annual Earnings } \\
\hline Self-Employed & $\$ 3,000$ & $\$ 8,000$ & $\$ 16,700$ & $\$ 26,908$ & $\$ 32,000$ & $\$ 55,200$ \\
\hline Wage/Salary & $\$ 9,768$ & $\$ 15,657$ & $\$ 24,313$ & $\$ 28,709$ & $\$ 36,300$ & $\$ 51,282$ \\
\hline \multicolumn{7}{|c|}{ Earnings Difference (Self-Employed - Wage/Salary) } \\
\hline Level & $-6,768$ & $-7,657$ & $-7,613$ & $-1,801$ & $-4,300$ & 3,918 \\
\hline \multirow[t]{2}{*}{ Percent (of Wage/Salary) } & 31 & 51 & 69 & 94 & 88 & 108 \\
\hline & \multicolumn{6}{|c|}{ Total Annual Earnings, Business Equity Adjusted } \\
\hline Self-Employed & $\$-1,000$ & $\$ 4,693$ & $\$ 13,600$ & $\$ 20,033$ & $\$ 27,750$ & $\$ 49,757$ \\
\hline Wage/Salary & $\$ 9,768$ & $\$ 15,657$ & $\$ 24,313$ & $\$ 28,709$ & $\$ 36,300$ & $\$ 51,282$ \\
\hline \multicolumn{7}{|c|}{ Earnings Difference (Self-Employed - Wage/Salary) } \\
\hline Level & $-10,768$ & $-10,964$ & $-10,713$ & $-8,676$ & $-8,550$ & $-1,525$ \\
\hline Percent (of Wage/Salary) & -10 & 30 & 56 & 70 & 76 & 97 \\
\hline \multicolumn{7}{|c|}{ Total Annual Earnings (including Capital Income), } \\
\hline Self-Employed & $\$-42,536$ & $\$ 3,600$ & $\$ 18,184$ & $\$ 25,314$ & $\$ 47,767$ & $\$ 115,648$ \\
\hline Wage/Salary & $\$ 10,600$ & $\$ 16,607$ & $\$ 25,496$ & $\$ 30,031$ & $\$ 37,843$ & $\$ 53,340$ \\
\hline \multicolumn{7}{|c|}{ Earnings Difference (Self-Employed - Wage/Salary) } \\
\hline Level & $-53,136$ & $-13,007$ & $-7,312$ & $-4,717$ & 9,924 & 62,308 \\
\hline Percent (of Wage/Salary) & -401 & 22 & 71 & 84 & 126 & 217 \\
\hline
\end{tabular}

Source: SIPP 1996 and 2001 panels 


\section{Table 4.}

Mean Annual Self-Employment Earnings by Ethnicity and Educational Attainment

\begin{tabular}{lcc}
\hline \multicolumn{1}{c}{ Self-Employed } & Hispanic & $\begin{array}{c}\text { White } \\
\text { (Non-Hispanic) }\end{array}$ \\
\hline & & \\
Less than High School & Annual Self-Employment & Earnings \\
High School & $\$ 12,057$ & $\$ 12,099$ \\
Some College & $\$ 14,916$ & $\$ 17,296$ \\
College Graduate & $\$ 21,334$ & $\$ 19,958$ \\
& $\$ 40,180$ & $\$ 34,378$ \\
& & \\
Less than High School & Business Equity Adjusted Annual Self-Employment Earnings \\
High School & $\$ 10,065$ & $\$ 9,223$ \\
Some College & $\$ 11,227$ & $\$ 11,443$ \\
College Graduate & $\$ 14,988$ & $\$ 14,306$ \\
& $\$ 32,097$ & $\$ 24,576$ \\
& & \\
Less than High School & Business Equity Adjusted Annual Self-Employment Earnings \\
High School & with Annual Change in Business Equity \\
Some College & $\$ 7,906$ & $\$ 12,191$ \\
College Graduate & $\$ 21,103$ & $\$ 16,376$ \\
\hline
\end{tabular}

Source: SIPP 1996 and 2001 panels 
Table 5. Decomposition of White - Hispanic Self-Employment Earnings Gap.

\begin{tabular}{|c|c|c|c|c|c|c|}
\hline Self-Employment Earnings Measure & \multicolumn{2}{|c|}{$\begin{array}{c}\text { (1) } \\
\text { Unadjusted }\end{array}$} & \multicolumn{2}{|c|}{$\begin{array}{c}(2) \\
\text { Business Equity Adjusted }\end{array}$} & \multicolumn{2}{|c|}{$\begin{array}{l}\text { (3) } \\
\text { Business Equity Adjusted } \\
\text { Change in Business Equity }\end{array}$} \\
\hline \multicolumn{7}{|l|}{ Predicted Mean Earnings } \\
\hline Hispanic women & \multicolumn{2}{|c|}{$\$ 18,697$} & \multicolumn{2}{|c|}{$\$ 14,391$} & \multicolumn{2}{|c|}{$\$ 16,808$} \\
\hline White women & \multicolumn{2}{|c|}{$\$ 23,316$} & \multicolumn{2}{|c|}{$\$ 16,441$} & \multicolumn{2}{|c|}{$\$ 20,001$} \\
\hline Observed Gap (White - Hispanic) & \multicolumn{2}{|c|}{$\$ 4,619$} & \multicolumn{2}{|c|}{$\$ 2,050$} & \multicolumn{2}{|c|}{$\$ 3,193$} \\
\hline \multirow[t]{2}{*}{ Blinder-Oaxaca } & \multicolumn{6}{|c|}{ Decomposition: Specific Contributions of Observed Characteristics } \\
\hline & $\$$ & $\%$ of Gap & $\$$ & $\%$ of Gap & $\$$ & $\%$ of Gap \\
\hline Education & 6,325 & $136.9 \%$ & 4,761 & $232.2 \%$ & 6,171 & $193.2 \%$ \\
\hline Potential Labor Market Experience & -52 & $-1.1 \%$ & -250 & $-12.2 \%$ & 1,149 & $36.0 \%$ \\
\hline Family Composition & -753 & $-16.3 \%$ & -652 & $-31.8 \%$ & $-3,578$ & $-112.1 \%$ \\
\hline Urban Resident & 646 & $14.0 \%$ & 355 & $17.3 \%$ & $-1,503$ & $-47.1 \%$ \\
\hline Immigrant/Years in U.S. & 3,266 & $70.7 \%$ & 3,192 & $155.7 \%$ & 4,019 & $125.9 \%$ \\
\hline Hours Work per Week & 193 & $4.2 \%$ & 127 & $6.2 \%$ & 231 & $7.2 \%$ \\
\hline Years in Business & 2,555 & $55.3 \%$ & 2,252 & $109.8 \%$ & 1,428 & $44.7 \%$ \\
\hline SIPP 2001 & -437 & $-9.5 \%$ & -513 & $-25.0 \%$ & 648 & $20.3 \%$ \\
\hline Total Due to Observed Characteristics & $\$ 11,744$ & $254.3 \%$ & $\$ 9,271$ & $452.2 \%$ & $\$ 8,564$ & $268.2 \%$ \\
\hline
\end{tabular}


Table 6. Observed and Predicted Hispanic Total Annual Earnings

\begin{tabular}{|c|c|c|c|}
\hline Total Annual Earnings Measure & $\begin{array}{c}(1) \\
\text { Unadjusted }\end{array}$ & $\begin{array}{c}\text { (2) } \\
\text { Business Equity Adjusted }\end{array}$ & $\begin{array}{c}\text { (3) } \\
\text { With Capital Income } \\
\text { Business Equity Adjusted } \\
\text { Change in Business Equity }\end{array}$ \\
\hline \multicolumn{4}{|l|}{ Observed Mean Earnings } \\
\hline Self-Employed & $\$ 20,853$ & $\$ 16,547$ & $\$ 18,554$ \\
\hline Wage/Salary & $\$ 21,133$ & $\$ 21,133$ & $\$ 21,988$ \\
\hline \multicolumn{4}{|l|}{ Observed Earnings Difference } \\
\hline Level (Observed Self-Employed - Observed Wage/Salary) & $-\$ 280$ & $-\$ 4,586$ & $-\$ 3,434$ \\
\hline Percent (of Observed Wage/Salary) & $98.7 \%$ & $78.3 \%$ & $84.4 \%$ \\
\hline \multicolumn{4}{|l|}{ Predicted Hypothetical Earnings } \\
\hline (1) Using Hispanic Wage/Salary Characteristics & $\$ 21,629$ & $\$ 18,305$ & $\$ 15,210$ \\
\hline \multicolumn{4}{|l|}{ Predicted Earnings Difference } \\
\hline Level (Predicted Self-Employed - Observed Wage/Salary) & $\$ 496$ & $-\$ 2,828$ & $-\$ 6,778$ \\
\hline Percent (of Observed Wage/Salary) & $102.3 \%$ & $86.6 \%$ & $69.2 \%$ \\
\hline $\begin{array}{l}\text { (2) Own Characteristics but Work in Wage/Salary Employment } \\
\text { Predicted Earnings Difference }\end{array}$ & 22,219 & $\begin{array}{l}\text { Same } \\
\text { as }\end{array}$ & 23,080 \\
\hline Level (Predicted Self-Employed - Observed Wage/Salary) & $\$ 1,087$ & Col. (1) & $\$ 1,092$ \\
\hline Percent (of Observed Wage/Salary) & $105.1 \%$ & & $105.0 \%$ \\
\hline
\end{tabular}




\section{Appendix}

Table A1. OLS Regressions of Self-Employment Earnings

\begin{tabular}{|c|c|c|c|c|c|c|}
\hline \multirow[t]{2}{*}{ Earnings Measure } & \multicolumn{2}{|c|}{ Self-Employment Earnings } & \multicolumn{2}{|c|}{$\begin{array}{l}\text { Self-Employment Earnings } \\
\text { Business Equity Adjusted }\end{array}$} & \multicolumn{2}{|c|}{$\begin{array}{l}\text { Self-Employment Earnings } \\
\text { Business Equity Adjusted } \\
\text { Change in Business Equity }\end{array}$} \\
\hline & Hispanic & White & Hispanic & White & Hispanic & White \\
\hline High School Graduate & $\begin{array}{c}2090.3 \\
(0.66)\end{array}$ & $\begin{array}{c}1385.4 \\
(0.81)\end{array}$ & $\begin{array}{l}957.9 \\
(0.29)\end{array}$ & $\begin{array}{c}-1034.2 \\
(0.52)\end{array}$ & $\begin{array}{c}14187.9 \\
(1.47)\end{array}$ & $\begin{array}{c}1278.6 \\
(0.17)\end{array}$ \\
\hline Some College & $\begin{array}{c}9455.5 \\
(2.43)\end{array}$ & $\begin{array}{c}4178.5 \\
(2.26)\end{array}$ & $\begin{array}{c}5106.5 \\
(1.41)\end{array}$ & $\begin{array}{c}1701.1 \\
(0.82)\end{array}$ & $\begin{array}{c}15382.9 \\
(1.61)\end{array}$ & $\begin{array}{c}3514.9 \\
(0.48)\end{array}$ \\
\hline College Graduate & $\begin{array}{c}28418.5 \\
(2.04)\end{array}$ & $\begin{array}{c}16470.2 \\
(7.48)\end{array}$ & $\begin{array}{c}22741.9 \\
(1.84)\end{array}$ & $\begin{array}{c}9888.7 \\
(4.10)\end{array}$ & $\begin{array}{c}23082.5 \\
(1.64)\end{array}$ & $\begin{array}{c}8623.5 \\
(1.11)\end{array}$ \\
\hline Potential Labor Market Experience & $\begin{array}{l}144.3 \\
(0.24)\end{array}$ & $\begin{array}{l}703.1 \\
(3.46)\end{array}$ & $\begin{array}{c}-289.0 \\
(0.50)\end{array}$ & $\begin{array}{l}492.1 \\
(2.20)\end{array}$ & $\begin{array}{c}2153.4 \\
(1.92)\end{array}$ & $\begin{array}{l}349.4 \\
(0.46)\end{array}$ \\
\hline Potential Labor Market Experience ${ }^{2} / 100$ & $\begin{array}{c}-415.8 \\
(0.38)\end{array}$ & $\begin{array}{c}-1530.1 \\
(3.63)\end{array}$ & $\begin{array}{l}328.2 \\
(0.31)\end{array}$ & $\begin{array}{c}-1212.0 \\
(2.71)\end{array}$ & $\begin{array}{c}-3072.4 \\
(1.54)\end{array}$ & $\begin{array}{c}-1096.6 \\
(0.71)\end{array}$ \\
\hline Married & $\begin{array}{c}-1294.0 \\
(0.42)\end{array}$ & $\begin{array}{l}-579.8 \\
(0.35)\end{array}$ & $\begin{array}{c}-4241.8 \\
(1.37)\end{array}$ & $\begin{array}{l}-573.9 \\
(0.34)\end{array}$ & $\begin{array}{c}10359.8 \\
(1.33)\end{array}$ & $\begin{array}{c}-3003.0 \\
(0.68)\end{array}$ \\
\hline Number of Children & $\begin{array}{c}2098.2 \\
(1.29)\end{array}$ & $\begin{array}{c}2481.0 \\
(2.74)\end{array}$ & $\begin{array}{l}292.6 \\
(0.18)\end{array}$ & $\begin{array}{c}1544.0 \\
(1.59)\end{array}$ & $\begin{array}{c}5212.0 \\
(0.95)\end{array}$ & $\begin{array}{l}210.6 \\
(0.08)\end{array}$ \\
\hline Number of Persons in Household & $\begin{array}{c}-430.1 \\
(0.49)\end{array}$ & $\begin{array}{c}-2402.8 \\
(3.49)\end{array}$ & $\begin{array}{l}272.9 \\
(0.31)\end{array}$ & $\begin{array}{c}-2222.9 \\
(2.89)\end{array}$ & $\begin{array}{c}1968.6 \\
(0.88)\end{array}$ & $\begin{array}{c}-2385.3 \\
(1.21)\end{array}$ \\
\hline Urban Resident & $\begin{array}{c}-4805.0 \\
(0.37)\end{array}$ & $\begin{array}{c}6364.7 \\
(5.89)\end{array}$ & $\begin{array}{c}-2637.8 \\
(0.23)\end{array}$ & $\begin{array}{l}6275.5 \\
(4.92)\end{array}$ & $\begin{array}{c}9901.8 \\
(0.99)\end{array}$ & $\begin{array}{c}4756.3 \\
(1.22)\end{array}$ \\
\hline Continued... & & & & & & \\
\hline
\end{tabular}




\begin{tabular}{|c|c|c|c|c|c|c|}
\hline Immigrant & $\begin{array}{c}-8646.7 \\
(1.98)\end{array}$ & $\begin{array}{c}-7632.9 \\
(1.83)\end{array}$ & $\begin{array}{c}-16434.8 \\
(3.45)\end{array}$ & $\begin{array}{c}-3366.4 \\
(0.79)\end{array}$ & $\begin{array}{c}22234.5 \\
(1.01)\end{array}$ & $\begin{array}{c}11431.2 \\
(0.80)\end{array}$ \\
\hline Years Since Immigration & $\begin{array}{l}538.1 \\
(1.16)\end{array}$ & $\begin{array}{l}829.2 \\
(1.58)\end{array}$ & $\begin{array}{c}1414.5 \\
(2.88)\end{array}$ & $\begin{array}{l}561.5 \\
(1.17)\end{array}$ & $\begin{array}{c}-2571.1 \\
(1.15)\end{array}$ & $\begin{array}{l}-242.9 \\
(0.17)\end{array}$ \\
\hline Years Since Immigration $2 / 100$ & $\begin{array}{c}-1652.3 \\
(1.68)\end{array}$ & $\begin{array}{l}-834.6 \\
(0.67)\end{array}$ & $\begin{array}{c}-3221.5 \\
(3.08)\end{array}$ & $\begin{array}{l}-400.6 \\
(0.36)\end{array}$ & $\begin{array}{l}3297.6 \\
(0.71)\end{array}$ & $\begin{array}{l}-363.6 \\
(0.12)\end{array}$ \\
\hline Hours Work per Week & $\begin{array}{c}93.9 \\
(0.90)\end{array}$ & $\begin{array}{l}116.6 \\
(3.49)\end{array}$ & $\begin{array}{c}61.6 \\
(0.67)\end{array}$ & $\begin{array}{c}69.6 \\
(1.79)\end{array}$ & $\begin{array}{c}98.4 \\
(0.36)\end{array}$ & $\begin{array}{l}220.1 \\
(1.68)\end{array}$ \\
\hline New Business (1 Year or Less) & $\begin{array}{c}-2579.5 \\
(0.65)\end{array}$ & $\begin{array}{c}-6029.4 \\
(3.95)\end{array}$ & $\begin{array}{l}-901.3 \\
(0.22)\end{array}$ & $\begin{array}{c}-6763.9 \\
(3.90)\end{array}$ & $\begin{array}{c}-9675.2 \\
(1.02)\end{array}$ & $\begin{array}{c}-6551.1 \\
(1.10)\end{array}$ \\
\hline Years in Business & $\begin{array}{c}1872.8 \\
(1.78)\end{array}$ & $\begin{array}{l}914.6 \\
(3.06)\end{array}$ & $\begin{array}{l}1664.6 \\
(1.74)\end{array}$ & $\begin{array}{l}554.3 \\
(1.88)\end{array}$ & $\begin{array}{l}570.6 \\
(0.26)\end{array}$ & $\begin{array}{l}-583.0 \\
(0.68)\end{array}$ \\
\hline Years in Business ${ }^{2} / 100$ & $\begin{array}{c}-3192.4 \\
(1.00)\end{array}$ & $\begin{array}{c}-1799.2 \\
(2.17)\end{array}$ & $\begin{array}{c}-2588.8 \\
(0.87)\end{array}$ & $\begin{array}{c}-1348.9 \\
(1.68)\end{array}$ & $\begin{array}{c}-1744.8 \\
(0.23)\end{array}$ & $\begin{array}{c}3418.6 \\
(1.30)\end{array}$ \\
\hline SIPP 2001 & $\begin{array}{c}5570.6 \\
(1.83)\end{array}$ & $\begin{array}{c}2807.4 \\
(2.07)\end{array}$ & $\begin{array}{l}6533.2 \\
(2.27)\end{array}$ & $\begin{array}{l}388.2 \\
(0.27)\end{array}$ & $\begin{array}{c}-6618.4 \\
(0.88)\end{array}$ & $\begin{array}{c}4047.0 \\
(1.04)\end{array}$ \\
\hline Intercept & $\begin{array}{c}5233.5 \\
(0.52)\end{array}$ & $\begin{array}{l}580.2 \\
(0.15)\end{array}$ & $\begin{array}{c}8788.7 \\
(0.93)\end{array}$ & $\begin{array}{c}5981.2 \\
(1.40)\end{array}$ & $\begin{array}{c}-49019.4 \\
(2.09)\end{array}$ & $\begin{array}{c}10287.4 \\
(0.67)\end{array}$ \\
\hline Number of Observations & 460 & 4,962 & 460 & 4,962 & 300 & 3,080 \\
\hline R-squared & 0.174 & 0.106 & 0.142 & 0.053 & 0.082 & 0.007 \\
\hline
\end{tabular}


Table A2. OLS Regressions of Hispanic Earnings

\begin{tabular}{|c|c|c|c|c|c|c|}
\hline \multirow[t]{2}{*}{ Earnings Measure } & \multicolumn{2}{|c|}{ Total Annual Earnings } & \multicolumn{2}{|c|}{$\begin{array}{l}\text { Total Annual Earnings } \\
\text { Business Equity Adjusted }\end{array}$} & \multicolumn{2}{|c|}{$\begin{array}{l}\text { Total Annual Earnings } \\
\text { and Capital Income, } \\
\text { Business Equity Adjusted } \\
\text { Change in Business Equity }\end{array}$} \\
\hline & Self-Employed & Wage/Salary & Self-Employed & Wage/Salary & Self-Employed & Wage/Salary \\
\hline Mexican Origin & $\begin{array}{c}-17.2 \\
0.00\end{array}$ & $\begin{array}{l}-560.7 \\
(0.97)\end{array}$ & $\begin{array}{c}1781.4 \\
(0.36)\end{array}$ & $\begin{array}{l}-560.7 \\
(0.97)\end{array}$ & $\begin{array}{c}-2659.3 \\
(0.33)\end{array}$ & $\begin{array}{l}-719.6 \\
(1.18)\end{array}$ \\
\hline High School Graduate & $\begin{array}{c}4619.4 \\
(1.11)\end{array}$ & $\begin{array}{l}4378.5 \\
(8.82)\end{array}$ & $\begin{array}{c}3668.3 \\
(0.91)\end{array}$ & $\begin{array}{c}4378.5 \\
(8.82)\end{array}$ & $\begin{array}{c}13517.2 \\
(1.36)\end{array}$ & $\begin{array}{c}4593.3 \\
(8.96)\end{array}$ \\
\hline Some College & $\begin{array}{c}10714.3 \\
(1.96)\end{array}$ & $\begin{array}{l}8331.8 \\
(11.64)\end{array}$ & $\begin{array}{l}7219.3 \\
(1.45)\end{array}$ & $\begin{array}{l}8331.8 \\
(11.64)\end{array}$ & $\begin{array}{c}12943.8 \\
(1.32)\end{array}$ & $\begin{array}{l}8778.0 \\
(11.16)\end{array}$ \\
\hline College Graduate & $\begin{array}{c}37231.1 \\
(1.81)\end{array}$ & $\begin{array}{c}21874.0 \\
(15.39)\end{array}$ & $\begin{array}{c}32093.8 \\
(1.71)\end{array}$ & $\begin{array}{c}21874.0 \\
(15.39)\end{array}$ & $\begin{array}{c}24870.0 \\
(1.75)\end{array}$ & $\begin{array}{c}22554.8 \\
(15.21)\end{array}$ \\
\hline Potential Labor Market Experience & $\begin{array}{l}1197.3 \\
(1.13)\end{array}$ & $\begin{array}{l}612.8 \\
(5.64)\end{array}$ & $\begin{array}{l}645.2 \\
(0.67)\end{array}$ & $\begin{array}{l}612.8 \\
(5.64)\end{array}$ & $\begin{array}{c}2600.1 \\
(2.34)\end{array}$ & $\begin{array}{l}659.8 \\
(6.01)\end{array}$ \\
\hline Potential Labor Market Experience ${ }^{2} / 100$ & $\begin{array}{c}-2056.7 \\
(1.14)\end{array}$ & $\begin{array}{c}-1093.9 \\
(5.00)\end{array}$ & $\begin{array}{c}-1121.7 \\
(0.68)\end{array}$ & $\begin{array}{c}-1093.9 \\
(5.00)\end{array}$ & $\begin{array}{c}-3739.1 \\
(1.84)\end{array}$ & $\begin{array}{c}-1121.9 \\
(5.07)\end{array}$ \\
\hline Married & $\begin{array}{c}-2473.7 \\
(0.78)\end{array}$ & $\begin{array}{c}1478.7 \\
(2.45)\end{array}$ & $\begin{array}{c}-5579.9 \\
(1.77)\end{array}$ & $\begin{array}{c}1478.7 \\
(2.45)\end{array}$ & $\begin{array}{c}10455.1 \\
(1.37)\end{array}$ & $\begin{array}{l}650.6 \\
(1.04)\end{array}$ \\
\hline Number of Children & $\begin{array}{c}2028.7 \\
(1.16)\end{array}$ & $\begin{array}{l}424.6 \\
(1.26)\end{array}$ & $\begin{array}{l}332.2 \\
(0.19)\end{array}$ & $\begin{array}{l}424.6 \\
(1.26)\end{array}$ & $\begin{array}{l}5403.1 \\
(1.01)\end{array}$ & $\begin{array}{l}865.4 \\
(2.38)\end{array}$ \\
\hline Number of Persons in Household & $\begin{array}{l}-789.5 \\
(0.84)\end{array}$ & $\begin{array}{l}-350.8 \\
(2.09)\end{array}$ & $\begin{array}{l}-50.9 \\
(0.05)\end{array}$ & $\begin{array}{l}-350.8 \\
(2.09)\end{array}$ & $\begin{array}{c}1419.4 \\
(0.66)\end{array}$ & $\begin{array}{l}-472.6 \\
(2.74)\end{array}$ \\
\hline Urban Resident & $\begin{array}{c}-8510.1 \\
(0.49)\end{array}$ & $\begin{array}{c}3628.9 \\
(4.83)\end{array}$ & $\begin{array}{c}-6471.8 \\
(0.41)\end{array}$ & $\begin{array}{c}3628.9 \\
(4.83)\end{array}$ & $\begin{array}{c}10664.2 \\
(1.05)\end{array}$ & $\begin{array}{c}3634.0 \\
(4.72)\end{array}$ \\
\hline
\end{tabular}




\begin{tabular}{|c|c|c|c|c|c|c|}
\hline Immigrant & $\begin{array}{c}-12496.5 \\
(2.51)\end{array}$ & $\begin{array}{c}-3990.2 \\
(4.92)\end{array}$ & $\begin{array}{c}-19873.1 \\
(4.24)\end{array}$ & $\begin{array}{c}-3990.2 \\
(4.92)\end{array}$ & $\begin{array}{c}20191.3 \\
(0.91)\end{array}$ & $\begin{array}{c}-4473.0 \\
(5.33)\end{array}$ \\
\hline Years Since Immigration & $\begin{array}{l}593.5 \\
(1.17)\end{array}$ & $\begin{array}{l}-78.6 \\
(0.78)\end{array}$ & $\begin{array}{c}1490.6 \\
(3.15)\end{array}$ & $\begin{array}{l}-78.6 \\
(0.78)\end{array}$ & $\begin{array}{c}-2591.9 \\
(1.13)\end{array}$ & $\begin{array}{l}-64.0 \\
(0.59)\end{array}$ \\
\hline Years Since Immigration ${ }^{2} / 100$ & $\begin{array}{c}-1574.6 \\
(1.50)\end{array}$ & $\begin{array}{l}666.3 \\
(2.39)\end{array}$ & $\begin{array}{c}-3243.0 \\
(3.20)\end{array}$ & $\begin{array}{l}666.3 \\
(2.39)\end{array}$ & $\begin{array}{c}3492.5 \\
(0.72)\end{array}$ & $\begin{array}{l}642.7 \\
(2.15)\end{array}$ \\
\hline Hours Work per Week & $\begin{array}{l}162.4 \\
(1.28)\end{array}$ & $\begin{array}{l}379.2 \\
(8.08)\end{array}$ & $\begin{array}{l}125.2 \\
(1.12)\end{array}$ & $\begin{array}{l}379.2 \\
(8.08)\end{array}$ & $\begin{array}{l}110.5 \\
(0.40)\end{array}$ & $\begin{array}{l}371.7 \\
(7.56)\end{array}$ \\
\hline SIPP 2001 & $\begin{array}{c}8125.1 \\
(1.87)\end{array}$ & $\begin{array}{c}3611.3 \\
(5.87)\end{array}$ & $\begin{array}{c}9022.6 \\
(2.27)\end{array}$ & $\begin{array}{c}3611.3 \\
(5.87)\end{array}$ & $\begin{array}{c}-6406.8 \\
(0.81)\end{array}$ & $\begin{array}{c}3808.9 \\
(5.89)\end{array}$ \\
\hline Intercept & $\begin{array}{c}1549.4 \\
(0.12)\end{array}$ & $\begin{array}{c}-10518.9 \\
(5.24)\end{array}$ & $\begin{array}{l}5108.1 \\
(0.45)\end{array}$ & $\begin{array}{c}-10518.9 \\
(5.24)\end{array}$ & $\begin{array}{c}-51243.9 \\
(2.21)\end{array}$ & $\begin{array}{c}-9988.0 \\
(4.63)\end{array}$ \\
\hline Number of Observations & 460 & 7,667 & 460 & 7,667 & 300 & 7,667 \\
\hline R-squared & 0.134 & 0.282 & 0.118 & 0.282 & 0.078 & 0.277 \\
\hline
\end{tabular}

